\title{
SPECIES AND SEX-SPECIFIC VARIATION IN THE ANTIOXIDANT STATUS OF TENCH, TINCA TINCA; WELS CATFISH, SILURUS GLANIS; AND STERLET, ACIPENSER RUTHENUS (ACTINOPTERYGII) REARED IN CAGE CULTURE
}

\author{
Remiguisz PANICZ ${ }^{*}$, Radosław DROZD ${ }^{2}$, Arleta DROZD³, and Arkadiusz NĘDZAREK ${ }^{4}$ \\ ${ }^{1}$ Division of Meat Sciences, Faculty of Food Sciences and Fisheries, West Pomeranian University of Technology, \\ Szczecin, Poland \\ ${ }^{2}$ Division of Immunology, Microbiology, and Physiological Chemistry, West Pomeranian University of Technology, \\ Szczecin, Poland \\ ${ }^{3}$ Division of Biochemistry and Human Nutrition, Pomeranian Medical University, Szczecin, Poland \\ ${ }^{4}$ Division of Aquatic Environmental Science, Faculty of Food Sciences and Fisheries, West Pomeranian University \\ of Technology, Szczecin, Poland
}

\begin{abstract}
Panicz R., Drozd R., Drozd A., Nędzarek A. 2017. Species and sex-specific variation in the antioxidant status of tench, Tinca tinca; wels catfish, Silurus glanis; and sterlet, Acipenser ruthenus (Actinopterygii) reared in cage culture. Acta Ichthyol. Piscat. 47 (3): 213-223.
\end{abstract}

Background. Oxidative stress poses a serious threat to farmed fish, exemplified by depressed growth, decreased disease resistance, and reduced flesh quality. Therefore, the aim of this study was to examine differences in activity of antioxidant enzymes and concentration of selected biochemical parameters between blood plasma of both sexes of three species important for sustainable development of aquaculture: tench, Tinca tinca (Linnaeus, 1758); wels catfish, Silurus glanis Linnaeus, 1758; and sterlet, Acipenser ruthenus Linnaeus, 1758.

Materials and methods. Experimental fishes were fed ad libitum for 60 days with a formulated diet $(45 \%$ proteins, $20 \%$ fat, $16 \%$ carbohydrates, $8 \%$ ash and $2 \%$ fibre). At the end of the study venous blood samples were collected and 11 biochemical parameters were assessed: superoxide dismutase (SOD), catalase (CAT), glutathione peroxidase (GPx), glutathione-S-transferase (GST), total antioxidant capacity (FRAP), alanine transaminase (ALT), aspartate transaminase (AST), lactate dehydrogenase (LDH), bilirubin, albumin, and uric acid.

Results. Comparison between species revealed that the most significant differences were observed for tench and sterlet (in FRAP, GPx, CAT, GST LDH, ALT, bilirubin, and uric acid), less significant-for sterlet and wels (in FRAP, GST, LDH, AST, bilirubin, uric acid), followed by tench and wels catfish (in FRAP, GPx, GST, AST, and uric acid). Moreover, significant variations in the level of biochemical markers were also detected between sexes within each species, where the highest number was observed for tench (in FRAP, GPx, albumin, and uric acid), next wells catfish (in SOD, albumin, and bilirubin), and the lowest in sterlet (in ALA). Additionally, numerous differences in antioxidant potential (FRAP), antioxidant defence indices, as well as in markers of liver function, heart dysfunction, and markers of nutritional status were observed as species-specific and sex-specific.

Conclusions. Results obtained in this study for the first time demonstrated species- and sex-related differences in plasma activity of antioxidant enzymes and concentration of selected biochemical parameters between tench, wels catfish, and sterlet reared in cage culture. The presented findings provide significant contribution not only to the existing knowledge of fish physiology but will also help to design optimal feeding practices to achieve sustainable cage aquaculture.

Keywords: antioxidative enzymes, oxidative stress, Polish aquaculture, reactive oxygen species, sturgeon

\section{INTRODUCTION}

Freshwater aquaculture in Poland is based on three major ways of fish farming such as: pond or irrigation ditch culture, cage culture, and integrated recycling systems (or raceways). The most efficient type of fish farming in Poland and 11 other northern European countries has been the cage culture (Tacon and Halwart 2007). The most important freshwater fishes reared in cages are: common 
carp, Cyprinus carpio Linnaeus, 1758; tench, Tinca tinca (Linnaeus, 1758); bighead carp, Hypophthalmichthys nobilis (Richardson, 1845) (Cyprinidae); wels catfish, Silurus glanis Linnaeus, 1758 (Siluridae); and sterlet, Acipenser ruthenus Linnaeus, 1758 (Acipenseridae). All the above-mentioned fish species along with rainbow trout, Oncorhynchus mykiss (Walbaum, 1792), make the bulk of Polish freshwater aquaculture production (Sadowski et al. 1998, Anonymous 2015). Despite all known advantages of cage farming, this approach is considered challenging due to limited possibilities to adjust culture parameters. The quantity and the composition of the administered feed or optimum stocking densities may be easily modified, whereas biochemical parameters of the surrounding aquatic environment are out of control (Blier 2014). Therefore, to maximize growth and product quality in cage culture, resolute steps should be taken to ensure high standards of fish welfare.

A quick and robust assessment of fish health can be achieved through determination of oxidative stress (OS) levels, for instance in blood samples. Aquaculture sector seeks out information on the mechanisms responsible for nutrient or environment-induced oxidative stress, because prolonged periods of oxidative stress pose serious problems to the farmed fish, exemplified by depressed growth, decreased disease resistance, and reduced flesh quality (Zhang et al. 2007). The phenomenon of OS is defined as temporarily or chronically elevated levels of reactive oxygen species (ROS) that alter the basic pathways of cell metabolism and can irreversibly damage cell structure (Lushchak 2011). Despite the threat posed by excess ROS, the endogenous ROS play an important role in signal transduction, apoptosis, and the defence against pathogens (Valko et al. 2007). The oxidative stress in cage-farmed fish is usually induced in response to the adverse synergistic effects of environmental factors. The most influential components include sudden changes in water temperature (Vinagre et al. 2012), variations in salinity (Da Rocha et al. 2009), improper nutrition (Enes et al. 2012), intense UV radiation (Häder et al. 2003), increased concentration of xenobiotics in aquatic environment (Bhattacharya 2001), and use of disinfectants (e.g., chlorine dioxide or formalin) (Tkachenko et al. 2013). The aforementioned factors affect behavioural and developmental parameters in fish. Therefore, species that depend only on oxygen dissolved in water and those capable of using atmospheric oxygen developed different metabolic pathways to maintain cellular oxidative stress homeostasis. The key role in managing levels of ROS, hence controlling response to OS, belong to antioxidant enzymes such as superoxide dismutase (SOD), catalase (CAT), glutathione peroxidase (GPx), glutathione reductase (GR), and indirectly, glutathione S-transferase (GST). In addition to those enzymes, the proper concentration of ROS is also maintained by lipophilic (vitamins A, E) and hydrophilic (vitamin C, metallothioneins, glutathione, uric acid) molecules. Physiological indicators of oxidative stress are also alanine transaminase (ALT), aspartate transaminase (AST), L-lactate dehydrogenase (LDH), bilirubin, and albumin (Yilmaz et al. 2006). Evaluation of mentioned above biochemical indices enables a thorough assessment of the physiological state and the well being of the fish and might be used to improve the quality and quantity of the fish production (Furné et al. 2009).

The scientific literature provides examples of how environmental and nutritional factors affect the oxidative system of various fish species (Enes et al. 2012, Vinagre et al. 2012). However, to the best of our knowledge, there are no available studies which describe speciesspecific changes in the level of antioxidant enzymes or other physiological indices of oxidative stress under unified farming conditions. Another interesting issue is sex-specific reaction to oxidative stress. Several results were published for the rainbow trout (O. mykiss), the chapultepec splitfin, Girardinichthys viviparous (Bustamante, 1837), or the European flounder, Platichthys flesus (Linnaeus, 1758) (see Williams et al. 1986, Vega-López et al. 2007, Kopecka and Pempkowiak 2008). However, those studies only assessed the influence of diverse factors in natural waters (e.g., heavy metals, PCBs, or pesticides) on the oxidant-antioxidant balance. Similar possible changes between different fish species reared under uniform farming conditions have not been assessed so far (Bhattacharya 2001). The lack of information on the above questions is important in the case of tench (EUR 4-5 per kg), wels catfish (EUR 6-8 per $\mathrm{kg}$ ), and sterlet (EUR 7-9 per kg), that are high value species for intensive cage farming not only in Poland but also in other countries which declare cage farming production.

For the reasons outlined above, the aim of this study was to examine hypothesis, if the response to oxidative stress, evaluated under unified cage farming conditions, is spices and sex dependent, by measuring selected biochemical parameters fish blood plasma. Results would contribute not only to increase knowledge about fish physiology but also to its optimization to achieve sustainable development of freshwater cage aquaculture.

\section{MATERIAL AND METHODS}

Experimental procedure and blood sampling. All three experimental species, tench, sterlet, and wels catfish, originated from the Fisheries Research Station in Nowe Czarnowo, Poland, and were farmed in cages placed in the cooling water discharge canal of the Dolna Odra power plant $\left(53^{\circ} 12^{\prime} 36^{\prime \prime} \mathrm{N}, 14^{\circ} 27^{\prime} 48^{\prime \prime} \mathrm{E}\right)$. A total of 100 $\mathrm{kg}$ of age $2+$ fish of each species were placed in separate $1.3 \times 1.43 \times 1.9 \mathrm{~m}$ cages with the production volume of $3 \mathrm{~m}^{3}$. The nutrition experiment was carried out for 60 days. During the study, the fish were fed ad libitum with a feed containing $45 \%$ proteins, $20 \%$ fat, $16 \%$ carbohydrates, $8 \%$ ash, and $2 \%$ fibre. The content of gross energy was $21.6 \mathrm{MJ} \cdot \mathrm{kg}^{-1}$ while that of digestible energy was $17.3 \mathrm{MJ} \cdot \mathrm{kg}^{-1}$. Other analysed ingredients included nitrogen (8.42\% dry mass), phosphorus (1.16\% dry mass), vitamin A (2500 IU $\cdot \mathrm{kg}^{-1}$ of feed), vitamin D3 (500 IU · $\mathrm{kg}^{-1}$ of feed), and vitamin E (100 mg $\cdot \mathrm{kg}^{-1}$ of feed). At the end of the last day of the experiment, fish from each cage 
were randomly selected and sampled. The specimens were anesthetized with 2-phenoxyethanol and $2 \mathrm{~mL}$ of blood collected from caudal artery. The blood samples were stored for $2 \mathrm{~h}$ at room temperature to form a clot and then centrifuged at $2000 \mathrm{rpm}$. Serum was collected from above the clot, aliquoted into $100 \mu \mathrm{L}$ portions, and stored at $-80^{\circ} \mathrm{C}$ until analysed.

Biochemical assays. The level of oxidative stress was measured based on the following set of serum biomarkers. The ferric reducing antioxidant power (FRAP) test was performed as previously described by Benzie and Strain (1996) and expressed as equivalent of ascorbic acid in $\mu \mathrm{M} \cdot \mathrm{L}^{-1}$. The glutathione peroxidase (GPx; EC 1.11.1.9) activity assay was performed using Ransel reagents (RNADOX Laboratories, Poland) and is based on the method of Paglia and Valentine (1967). The glutathione S-transferase (GST; EC 2.5.1.18) activity was measured according to Habig et al. (1974). Catalase (CAT; EC 1.11.1.6) activity was assessed by a decrease in absorption of $\mathrm{H}_{2} \mathrm{O}_{2}$ at $240 \mathrm{~nm}$ due to degradation as described by $\mathrm{Li}$ and Schellhorn (2007). Superoxide dismutase (SOD; EC 1.15.1.1) was determined spectrophotometrically in all the study groups by the method devised by Marklund and Marklund (1974). All above-listed assays were described in detail by Drozd et al. (2014). Liver and heart condition was assessed based on three biochemical markers. Alanine transaminase (ALT; EC 2.6.1.2) and aspartate transaminase (AST; EC 2.6.1.1) were determined according to the method described by Thefeld et al. (1973), using an appropriate kinetic assay kit according to the manufacturer's protocol (BioMaxima S.A., Lublin, Poland). L-lactate dehydrogenase (LDH; EC 1.1.1.27) was measured according to Bergmeyer and Bernt (1974) using Alpha Diagnostics (Poland) enzyme test. The activity of the analysed enzymes was expressed in $\mathrm{U} \cdot \mathrm{mg}^{-1}$ of protein. In the presented paper four other biochemical parameters of blood plasma were also included into the analysis. Uric acid, a water-soluble antioxidant, was assayed with an enzymatic method according to Tietz (1999) using a diagnostic kit (Biolabo, France), and expressed in $\mu \mathrm{M}$. Total bilirubin, chain-breaking antioxidant, was measured according to Michaelsson (1961) using a commercial kit (BioMaxima, Poland), and expressed in $\mathrm{mg} \cdot \mathrm{dL}^{-1}$. Total albumin, serum biomolecules transporter, was measured according to Doumas et al. (1971) using the Liquick Cor-Albumin kit (PZ. Cormay SA, Poland), and expressed in $\mathrm{g} \cdot \mathrm{dL}^{-1}$. Total plasma proteins were measured according to Bradford (1976) against bovine serum albumin as a standard.

Hydrochemical analysis of the cage culture treatments. Hydrochemical characteristics of water flowing through experimental cages were assessed to provide complete environmental background and were determined according to the methodology recommended by the Clesceri et al. (1998). Titrimetric methods were used to determine the overall alkalinity (hydrochloric acid to methyl orange), chloride ions (the Mohr method), total hardness, as well as the calcium and magnesium ions (the complexometric methods of disodium edetate to eriochrome black $\mathrm{T}$ and murexide). Particular forms of nitrogen, phosphorus, sulphates, chlorophyll-a, and total iron were determined using colorimetric methods. The UV-VIS spectrophotometer Pharo 300 Spectroquant (by Merck) was used in the colorimetric methods, measuring the absorbance at the recommended wavelengths $(\lambda)$. Inorganic forms of nitrogen (nitrite, nitrate, and ammonium), total nitrogen (TN), total reactive phosphorus (TRP), and total phosphorus (TP) were analysed in water samples without filtration. Total chlorophyll-a was measured by filtrating $500 \mathrm{~mL}$ of water onto the Whatman $\mathrm{GF} / \mathrm{C}$ filters stored at $-20^{\circ} \mathrm{C}$ until analysis. Chlorophyll was extracted using 90\% acetone $(\lambda=665 \mathrm{~nm})$. Absorbance values were measured on a Spectroquant Pharo 300 Merck spectrophotometer. Nitrite nitrogen was assayed with sulphanyl acid $(\lambda=453 \mathrm{~nm})$. Nitrate-nitrogen was determined as nitrites after reduction on a $\mathrm{Cu}-\mathrm{Cd}$ column. Ammonium nitrogen was assayed with indophenol blue $(\lambda=630 \mathrm{~nm})$. TN was determined as nitrates after mineralization with potassium hypersulphate. The total organic nitrogen (TON) content was calculated as the difference between $\mathrm{TN}$ and total inorganic nitrogen (TIN) (sum of nitrite, nitrate, and ammonium nitrogen contents). TRP was assayed using the molybdate test with ascorbic acid as a reducer $(\lambda=882 \mathrm{~nm})$. TP was assayed as TRP after mineralization with potassium hypersulphate. The difference between the two phosphorus fractions produced total organic phosphorus (TOP). Additionally, sulphates were assayed with barium chloride $(\lambda=420 \mathrm{~nm})$. Total iron was assayed with phenanthroline $(\lambda=510 \mathrm{~nm})$. Chemical oxygen demand $\left(\mathrm{COD}_{\mathrm{Cr}}\right)$ was assayed using bichromate according to Clesceri et al. (1998). Biological oxygen demand $\left(\mathrm{BOD}_{5}\right)$ was determined using a direct method after a five-day incubation of the samples with no access of light at a constant temperature of $20^{\circ} \mathrm{C}$. The concentrations of oxygen dissolved in water were determined using the Winkler titration. Total suspended solids (TSS) were determined by weight. Water $\mathrm{pH}$ was measured using the CP-103 pH-meter (Elmetron) while conductance was measured using the CC-101 conductivity meter (Elmetron).

Statistical analyses. All statistical analyses of the obtained blood serum parameters were conducted using the STATISTICA 10 software by StatSoft. The analysis of the distribution of variables was assessed using the ShapiroWilk significance test, assuming statistical significance at $P<0.05$. While the majority of the variables were not normally distributed further tests were performed using nonparametric tests. The comparison of the mean levels of each parameter between the sexes within each species was performed using the Mann-Whitney $U$ test. The mean levels of the parameters compared between each analysed species were assessed using the Kruskal-Wallis test followed by the Dunn's multiple comparison test.

This experiment was approved by the Ethical Committee for Animal Experiments of the West Pomeranian University of Technology, Szczecin, Poland. 


\section{RESULTS}

Hydrochemical results. Analyses of water samples from each treatment/cage were conducted to assure the uniformity of the parameters, which could influence biochemical parameters in fish blood. Only insignificant variations were observed. Water $\mathrm{pH}$ was the lowest in the sterlet cage $(\mathrm{pH} 7.2)$ while the highest in the tench cage (pH 7.8). A similar pattern was noted for conductance (601 and $617 \mu \mathrm{S} \cdot \mathrm{cm}^{-1}$, respectively). Among the identified inorganic forms of nitrogen, nitrate nitrogen was prevalent and its concentrations ranged from 0.431 to $0.537 \mathrm{mgN} \cdot \mathrm{L}^{-1}$ (the mean concentration of $\mathrm{N}^{-\mathrm{NO}_{3}}{ }_{3}^{-}$for the analysed cages was $0.489 \mathrm{mgN} \cdot \mathrm{L}^{-1}$ ), the concentrations of ammonium nitrogen ranged from 0.072 to $0.084 \mathrm{mgN} \cdot \mathrm{L}^{-1}$ (mean $\left.0.078 \mathrm{mgN} \cdot \mathrm{L}^{-1}\right)$, and the concentrations of nitrite nitrogen ranged from 0.035 to $0.037 \mathrm{mgN} \cdot \mathrm{L}^{-1}$. Inorganic nitrogen represented, 93\% total nitrogen. The concentrations of total reactive phosphorus were in the range of $0.082-$ $0.086 \mathrm{mg} \mathrm{P} \cdot \mathrm{L}^{-1}$ and this form of phosphorus represented, $72 \%$ total phosphorus which concentrations ranged from 0.114 to $0.121 \mathrm{mg} \mathrm{P} \cdot \mathrm{L}^{-1}$. The highest total alkalinity and total hardness values were also recorded in the tench cage (139.12 and $227.7 \mathrm{mg} \cdot \mathrm{L}^{-1}$, respectively), and the mean values of these parameters were 137.12 and 219.19 $\mathrm{mg} \cdot \mathrm{L}^{-1}$, respectively. The mean concentrations of sulphate, chloride, calcium, and magnesium were 73.85, 79.3, 65.86 , and $26.53 \mathrm{mg} \cdot \mathrm{L}^{-1}$, respectively. The concentration of organic matter was the highest in the sterlet cage, and the level of $\mathrm{BOD}_{5}, \mathrm{COD}_{\mathrm{Cr}}$, and chlorophyll-a in the water from this cage were $8.0 \mathrm{mg} \mathrm{O} \cdot \mathrm{L}^{-1}, 27.8 \mathrm{mg} \mathrm{O}_{2} \cdot \mathrm{L}^{-1}$, and $13.88 \mathrm{mg} \cdot \mathrm{L}^{-1}$, respectively, while the mean levels of these parameters were $5.6,25.1$, and $11.39 \mathrm{mg} \cdot \mathrm{L}^{-1}$, respectively. The concentrations of dissolved oxygen in water ranged from 7.31 to $7.62 \mathrm{mg} \mathrm{O}_{2} \cdot \mathrm{L}^{-1}$.

Comparative analyses of biochemical parameters. The results obtained from the biochemical assays, presented as mean values with variation (SD), revealed differences between the groups of tench, wells catfish, and sterlet, as well as within each group between sexes (Table 1). The highest number of significant differences between mean values, was observed for tench and sterlet (in FRAP, GPx, CAT, GST, LDH, ALT, bilirubin, and uric acid), followed by sterlet and wels catfish (in FRAP, GST, LDH, AST, bilirubin, and uric acid) and were the lowest for tench and wels catfish (in FRAP, GPx, GST, AST, and uric acid). Among 11 tested variables, insignificant differences were only observed for SOD and albumin. As for the significant differences between sexes within each species, the highest number was observed for tench (in FRAP, GPx, albumin, and uric acid), followed by wells catfish (in SOD, albumin, and bilirubin), and the lowest for sterlet (in ALA). Significant differences between biochemical parameters were depicted in Fig. 1.

Antioxidant status of plasma by FRAP. The analysis of the antioxidant potential measured by FRAP indicated a high diversity of the parameter between the analysed species (Fig. 1A) and sexes (Table 1). The highest FRAP value was found in tench $(P<0.001)$ and was nearly 10 times higher than for the other analysed species. The lowest FRAP values were recorded for the wels catfish. The values were close to those obtained for sterlet (the same order of magnitude), however, the significance of the differences was at $P<0.01$. Significant differences in the FRAP levels were also found in relation to gender. In tench females, the values of this parameter were significantly higher than in tench males $(P$ $<0.01)$. In the case of sterlet and wels catfish, no significant differences in this parameter were found between the males and the females.

Enzymes of antioxidant defence. The significantly higher GPx activity was observed in tench, when compared to wels catfish and sterlet $(P<0.001)$ (Fig. 1B). In addition, there was a significantly higher activity of glutathione peroxidase in tench males than in females $(P<0.01)$. No differences in the GPx activity were found between males and females of the other analysed fish species (Table 1). Also, the catalase activity (CAT) was evidently higher in tench than in the other species. However, the significant difference was only observed for the tested pair of tench and sterlet $(P<0.001)$ (Fig. 1C). There was no considerable difference in CAT activity between males and females of the analysed species (Table 1). Analysis of GST revealed the highest enzyme activity in the blood serum of tench $(P<0.001)$ while the lowest in sterlet $(P<0.001)$ (Fig. 1D). Whilst superoxide dismutase (SOD) activity was comparable in all analysed species, wels catfish females displayed significantly higher activity than males $(P<0.05)$ (Table 1$)$.

LDH, ALT, and AST activity. Measurements of lactate dehydrogenase (LDH) demonstrated seven times higher enzyme activity in the sterlet $(P>0.001)$ in comparison tench and wels catfish, among which no differences in the LDH activity were observed (Fig. 1E). No differences in the LDH activity were reported between the sexes of each species (Table 1). Analysis of the AST activity in the blood serum of each species showed a significantly higher activity $(P<0.001)$ in wels catfish compared to the other species (Fig. 1F). Similarly to LDH, no significant differences in relation to sex were detected. The ALT activity analysis revealed a significant difference only between tench and sterlet $(P<0.05)$ (Fig. 1G). The significant difference in ALT activity between male and females $(P<0.05)$ was only observed for sterlet, with females displaying higher values that males (Table 1).

Albumin, bilirubin, and uric acid. The determined albumin concentration was comparable in all analysed species. However, there was a sex related increase $(P<$ 0.01 ) of the albumin concentration in tench and wels catfish females when compared with males of the same species (Table 1). The content of bilirubin was significantly higher $(P<0.001)$ in sterlet than in the other two species (Fig. $1 \mathrm{H})$. In relation to sex, significant differences were only found in wels catfish in which the bilirubin concentration was significantly higher in the blood serum of the males than the females $(P<0.05)$ (Table 1). The highest concentration of uric acid was observed in tench blood serum $(P<0.001)$ (Fig. 1I). In addition, in the females of this species, the concentration of uric acid was almost two times higher than in the males $(P<0.001)$ (Table 1). 


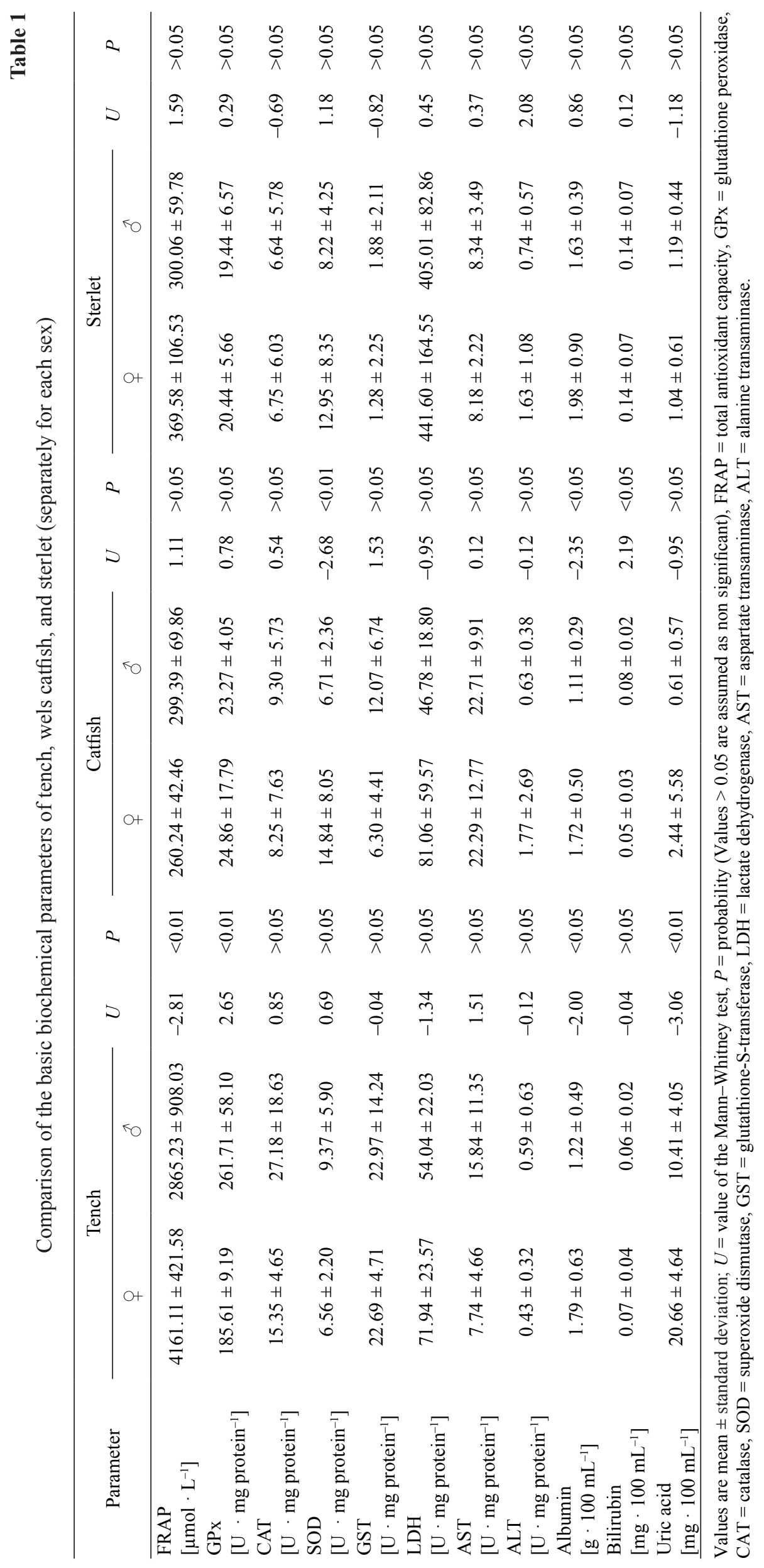




\section{DISCUSSION}

Cage farming depends largely on the surrounding environment and the way the culture is conducted, with a feed as the critical factor. However, the rising cost of feed production (with the fish oil as the main component), due to dwindling natural fish resources, focused the attention of fish framers on species of hitherto secondary importance capable of utilizing alternative feed components, such as omnivorous tench. (Olsen 2011). Tench, the candidate species for sustainable freshwater aquaculture, is known
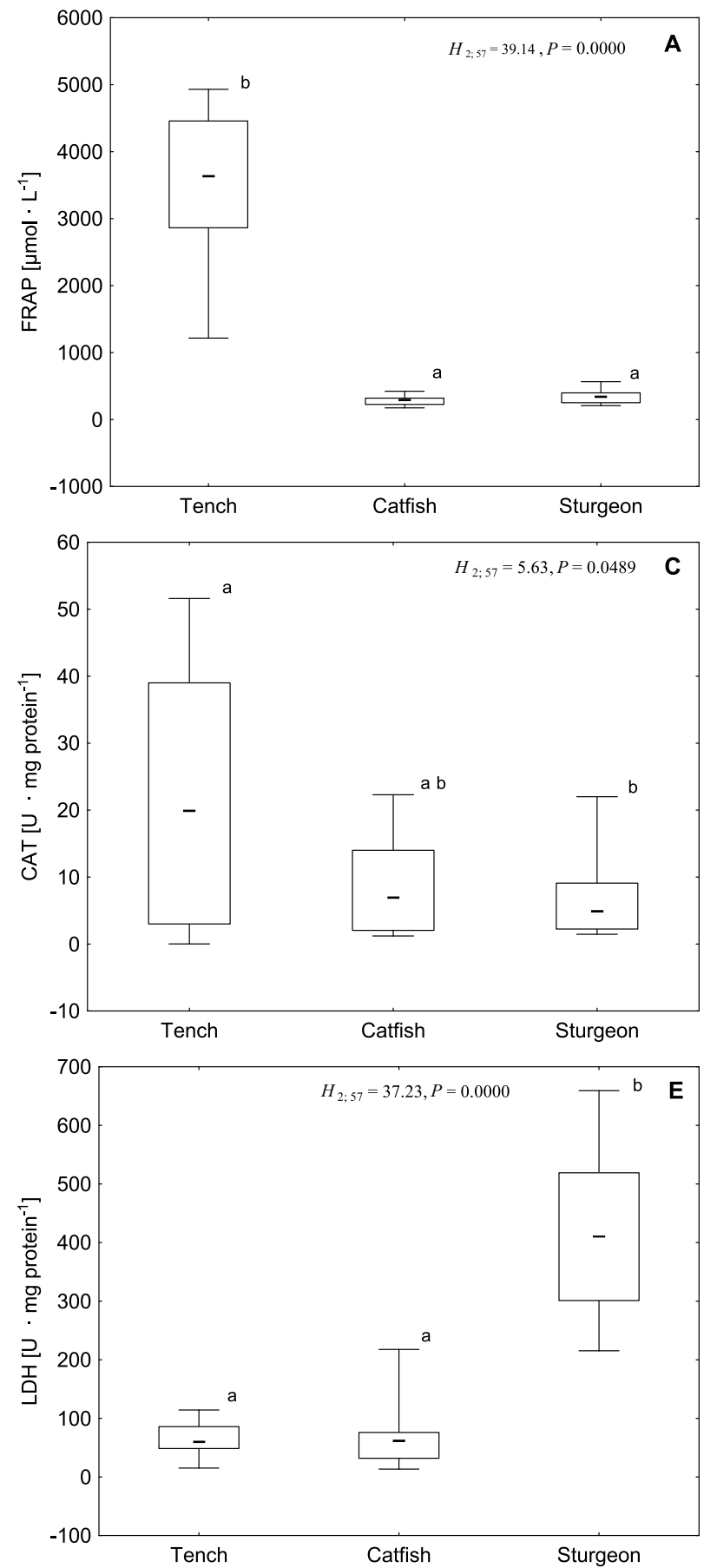

for its slow growth rate and for this reason, fish feed producers did not develop any specific fodder for this species as they did for carp, salmon, sturgeon, or other principal species. Therefore, feeding tench with feed developed for other species may result in an increased oxidative stress, measured by a specific change in values of plasma biochemical markers (Jiang et al. 2015). In this study, we describe species-specific (Fig 1) and sex-specific (Table 1) differences in the level of biochemical indices in plasma of tench, sturgeon and wells catfish from cage
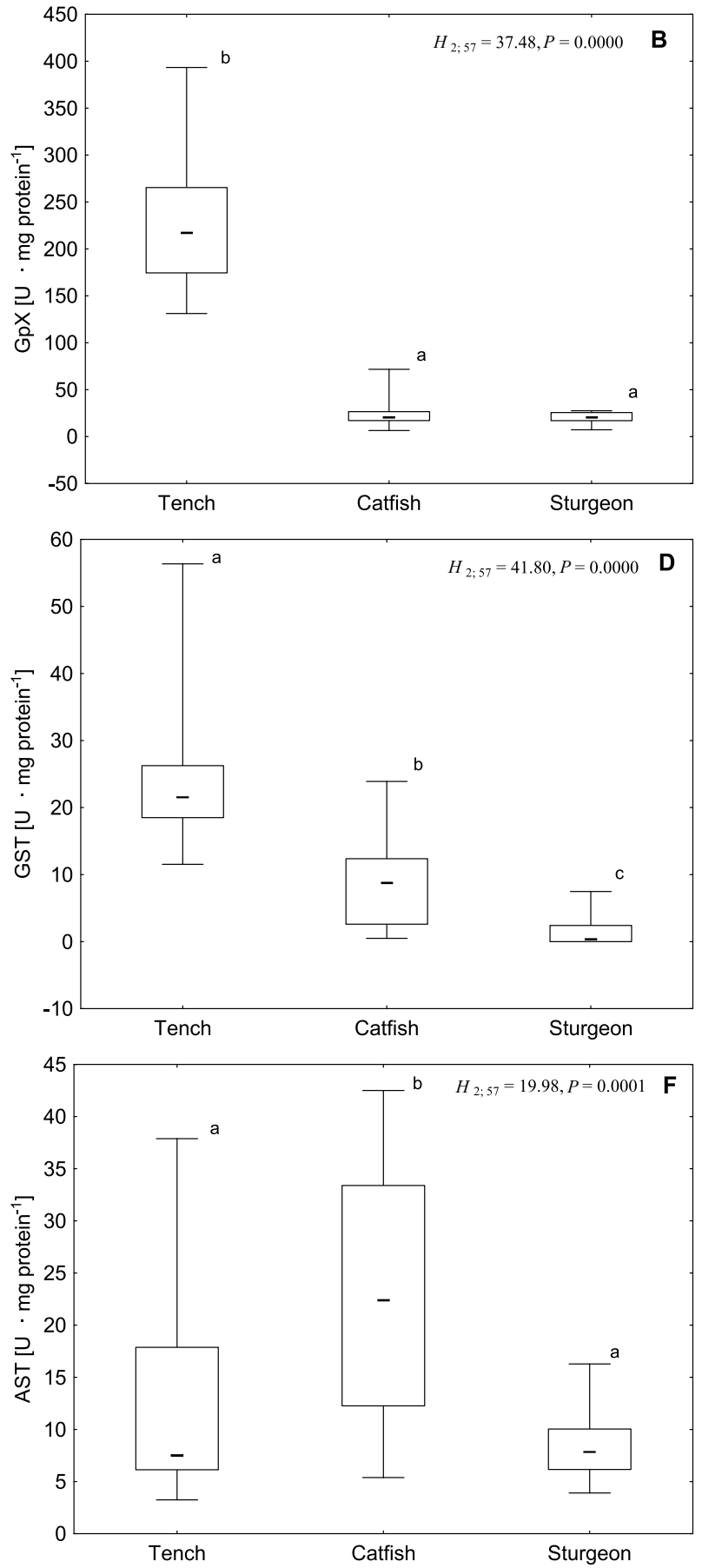

Fig. 1. Comparison of the mean levels of the analysed biochemical parameters in the blood plasma of tench, wels catfish, and sterlet using the Kruskal-Wallis test; $H=$ statistic of the Kruskal-Wallis test, $P=$ calculated probability $(P$-value), Degrees of freedom: $\mathrm{df}=2(k=3)$; Homogenous groups share identical scripts; Non significant differences between blood levels of SOD and albumin were not displayed 
culture. The presently reported comparative analysis of the mean levels of oxidative stress markers in the plasma demonstrated that tench individuals display significantly higher levels of oxidative stress in comparison to the other two species. Above-mentioned observation also provided information on the oxidative load and operational efficiency of the antioxidant system. This was the most apparent after juxtaposing the mean values calculated for FRAP, GPx, CAT, and GST. SOD was the only enzyme, which did not show significant differences between
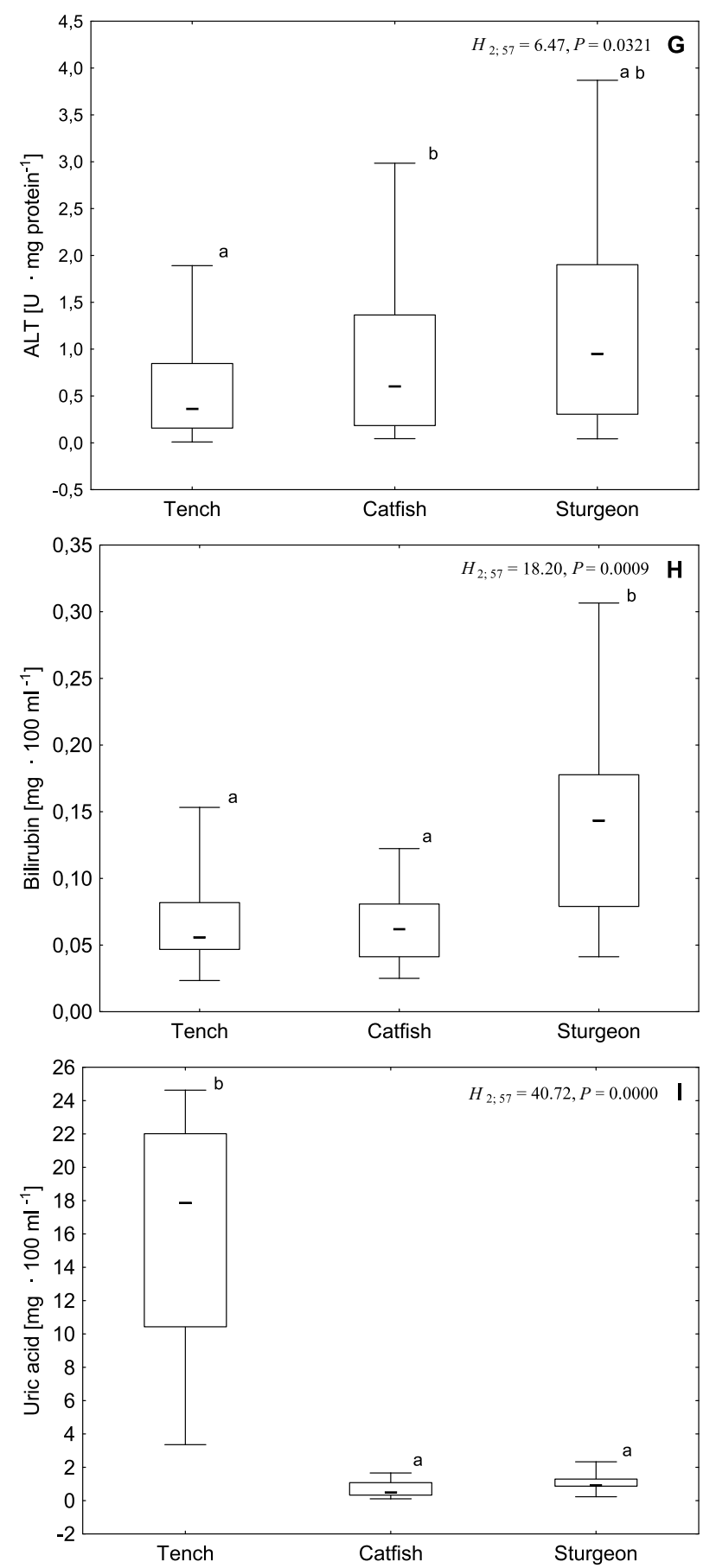

Fig. 1. Continuation studied species. An interesting fact is that FRAP, GPx, CAT, and GST levels documented for sterlet were always lower in comparison to tench (Fig. 1A-D). According to some authors, the difference between antioxidant enzymes activities correlate with the species phylogenetic position where ancestral species exhibit the lower activity of those enzymes (Rudneva 1997). Moreover, sturgeons consume lower levels of oxygen which can also explain lower activity observed for antioxidant enzymes (Rabie et al. 1972). According to Passi et al. (2002) the observed differences may reflect a species-specific response to diet, as it was also observed for different species of fish, cephalopods or crustaceans. The results observed for tench, were additionally tested by an aside aquarium experiment (undescribed here), where twelve tench individuals were held for one week in spring water RAS system, under identical feeding regime. Laboratory analysis determined that the biochemical parameters were comparable with results obtained for tench from the master experiment. The authors would like to emphasize that the lack of specific feed for tench may lead to increased oxidative stress, which may de facto result from the inappropriately balanced diet which is inadequate for tench digestion tract, due to lack of the stomach. In the course of evolution (starting 450 MYA), the tench belonging to family Cyprinidae, similarly to the fish of six other genera, did not develop the stomach which important function is protein digestion (Koelz 1992, Nelson et al. 2016). In light of the above, interesting results were published by González-Rodríguez et al. (2014) who tested the usefulness of feedstuffs with different protein content, ranging from $40 \%$ to $60 \%$, on six months old tench individuals. They concluded that immature tench exhibited the highest growth rate (FCR 1.61 ) when the feed containing $48 \%$ to $52 \%$ proteins. However, the growth rate of adult trench individuals feed with $45 \%$ of protein diet was not affected. This is likely due to the lower requirement of protein by adult fish as it was demonstrated in the study with carp (Sen et al. 1978).

Another important feed component is fat, which accounted for $20 \%$ of the feed used in the experiment. Wels catfish and, to a lesser extent, sterlet utilize such feed, however in the case of the tench, $20 \%$ fat content may cause pathological changes in the liver structure (Przybył et al. 2008, Amirkolaie et al. 2012). Results published by Demska-Zakęś et al. (2012) demonstrated hepatocyte damage caused by as low as $12 \%$ fat content in administered feed. Increasing in AST and LDH activity in plasma is usually associated with liver damage due to release of these enzymes into the blood stream from hepatocytes (Ciereszko and Dąbrowski 1994). Comparative analysis of LDH demonstrated significantly higher levels in sterlet serum as compared with wels catfish and tench (Fig. 1E). The observed difference depicts presumably species-specific response since the LDH values exceeding $400 \mathrm{U} \cdot \mathrm{L}^{-1}$ were reported earlier for sterlet (Piros et al. 2002). In the case of wels catfish and tench, usually, lower values were observed (Adedeji et al. 2009, Dai et al. 2011).

Results published by He et al. (2015), demonstrated that not only LDH, but also ALT, and AST may also be 
used as biochemical markers of improperly designed diet of fish. Both transaminases are predominantly markers of liver function and may reflect improperly balanced diet resulting from total protein content. The influence of protein content in the diet on the activities of transaminases has been described for the rainbow trout (Oncorhynchus mykiss) (see Lupiánez et al. 1989). In the presently reported study, significant differences between AST and ALT were observed for the analysed species (Fig. 1F, G), however, they could not explicitly confirm that the observed speciesspecific differences in the activity of transaminases resulted from improper nutrient levels in feed. Another important indicator of fish liver function is the level of bilirubin in blood plasma (Mehra et al. 2009). Among the analysed species the highest level of bilirubin was observed for sterlet (Table 1, Fig. 1H). However, comparison of bilirubin levels within the family Acipenseride, showed higher values for starry sturgeon, Acipenser stellatus Pallas, 1771 (0.616 \pm $0.023 \mathrm{mg} \cdot \mathrm{L}^{-1}$ ) and hybrids of Adriatic sturgeon, Acipenser naccarii Bonaparte, $1836 \times$ Siberian sturgeon, Acipenser baeri Brandt, 1869 than to presented here sterlet $(0.14 \pm$ $0.06-0.30 \mathrm{mg} \cdot \mathrm{L}^{-1}$ for female and $0.15 \pm 0.04-0.26 \mathrm{mg}$. $\mathrm{L}^{-1}$ for male) (Shahsavani et al. 2010, Di Marco et al. 2011). In pathological cases associated with fish exposure to toxins or improperly balanced feed, increased the level of bilirubin is linked to higher activity of LDH but such dependence was not observed for sterlet (Roy and Bhattacharya 2006).

Sex-specific reactions of fish to oxidative stress have been previously described in species such as the rainbow trout, O. mykiss; the chapultepec splitfin, Girardinichthys viviparus; or the European flounder, Platichthys flesus (see Williams et al. 1986, Vega-López et al. 2007, Kopecka and Pempkowiak 2008). However, those studies mainly assessed the oxidant-antioxidant balance in wild fish but not from culture fish where the feeding plays a significant role. In this paper we report the finding of a gender-dependent response to diet. The most significant differences in the tested biochemical parameters were noted between the males and the females of tench (in FRAP, GPx, albumin, and uric acid), then wels catfish (in SOD, albumin, and bilirubin), and sterlet (ALA) (Table 1). The differences in the levels of FRAP, GPx, uric acid, and albumin between the blood plasma samples collected from the females and the males are particularly intriguing. These indices constitute a direct evidence of the genderrelated response to diet between the tench males and females. Previously described differences for tench sexes included sexual size dimorphism phenomenon (Panicz et al. 2015). Experiments in pond demonstrated that females grew faster than males, whereas aquarium trials revealed the sex-specific activity of somatotrophic axis assessed based on GH and IGF1 levels.

The higher FRAP levels in the blood plasma of females have already been reported in other species, such as rats or turkeys (Katalinic et al. 2005, Ognik et al. 2013). However, this study for the first time presents such a sexspecific response in T. tinca. According to many authors, such relation may be influenced by sex hormones specific to each sex. Both testosterone and estradiol may directly modulate the rate and the direction of metabolic processes, thereby affecting the proper functioning of the organism (Hoogenboom et al. 2012). In addition to FRAP, female's blood plasma also carried higher levels of uric acid (Table 1). This correlation is a result of the properties or uric acid, which levels closely correlate with the established FRAP concentrations (Benzie and Strain 1996). High levels of this compound have been reported previously for numerous fish species, including the tench, for which the concentration of uric acid in the seminal plasma was determined at $148.0 \pm 9.3 \mu \mathrm{M}$ (Ciereszko et al. 1999).

The third important biomarker which concentration in the females was significantly higher than in the males is albumin. Albumin is one of the negative acute phase markers and an indicator of nutritional status. In the group of antioxidants, consisting of transferrin, ceruloplasmin, haptoglobin, vitamin E, and glucose, albumin is considered to play the most important role in counteracting oxidative stress (Sitar et al. 2013). Results of Kovyrshina and Rudneva (2012) demonstrated higher albumin levels in females. However, there are reports presenting an opposite relation (Yousefian et al. 2010). The different albumin levels in both sexes depend on the degree of sexual maturity, and the length of time during which females and males become ready for spawning in a given season (Di Marco et al. 2011). The tench females (2+ years) reach sexual maturity in the third year and prepare for spawning in the spring and summer, during the gradual increase of water temperature (Macrì et al. 2011). Therefore, the higher levels of albumin observed in the blood plasma of tench females were possibly due to the increased albumin demand for the formation of gonads and the production of spawn. The analysis of the GPx levels revealed a significantly higher activity of this enzyme in the plasma of tench males. In relation to sex, different levels of the GPx activity were previously reported only for three-spined stickleback, Gasterosteus aculeatus Linnaeus, 1758 (see Sanchez et al. 2007). However, the latter study described higher GPx activity for females. Despite the numerous reports describing the hormonal changes occurring in sexually mature vertebrates (Mull et al. 2010), for example, in tench (Table 1), the mode in which sex hormones affect oxidative stress is still largely unexplored and requires further research.

The presently reported study is a continuation and expansion of previous studies, in which the effect of three farming systems (environments) on the antioxidant status of liver and gills in tench, was assessed (Drozd et al. 2014). The results obtained in this study describe differences in the plasma levels of various antioxidant enzymes and physiological indices of oxidative stress between cage-cultured tench, sturgeon, and wells catfish and their sexes. Since feeding plays a pivotal role in a cage farming, the differences observed in our study were discussed in relation to the assumed influence of unbalanced feed on fish physiology, mainly tench. To the best of our knowledge, this is the first report, in which such comparison has been made for three species important for freshwater aquaculture. 


\section{ACKNOWLEDGMENTS}

We thank Prof. Jacek Sadowski and Marek Bartłomiejczyk for making available the fishes used in this study and Dr Agnieszka Sompolska-Rzechuła for assistance in the statistical analysis.

\section{REFERENCES}

Adedeji O.B., Adeyemo O.K., Agbede S.A. 2009. Effects of diazinon on blood parameters in the African catfish (Clarias gariepinus). African Journal of Biotechnology 8 (16): 3940-3946.

Amirkolaie K.A., Mahdavi S., Hosseini S.A. 2012. Dietary fat content and feed supply influence growth and body composition in juvenile beluga sturgeon (Huso huso). Aquaculture International 20 (5): 859-867. DOI: $10.1007 / \mathrm{s} 10499-012-9507-7$

Anonymous 2015. National aquaculture sector overview; Poland. Fisheries and Aquaculture Department, FAO, Rome. http://www.fao.org/fishery/countrysector/ naso_poland/en\#tcN70085

Benzie I.F.F., Strain J.J. 1996. The ferric reducing ability of plasma (FRAP) as a measure of "antioxidant power": the FRAP assay. Analytical Biochemistry 239 (1): 70-76. DOI: 10.1006/abio.1996.0292

Bergmeyer H.U., Bernt E. 1974. Lactate dehydrogenase. UV-assay with pyruvate and NADH. Pp. 254-259. In: Bergmeyer H.-U. (ed.) Methods of enzymatic analysis. 2nd edn. Academic Press, New York, NY, USA. DOI: 10.1016/B978-0-12-091302-2.50001-3

Bhattacharya S. 2001. Stress response to pesticides and heavy metals in fish and other vertebrates. Proceedings of the Indian National Science Academy B67 (5): 215-246.

Blier P. 2014. Fish health: An oxidative stress perspective. Fisheries and Aquaculture Journal 5: e105. DOI: $10.4172 / 2150-3508.1000 \mathrm{e} 105$

Bradford M.M. 1976. A rapid and sensitive method for quantitation of microgram quantities of protein utilizing the principle of protein-dye binding. Analytical Biochemistry 72 (1-2): 248-254. DOI: 10.1016/0003-2697(76)90527-3

Ciereszko A., Dabrowski K. 1994. Relationship between biochemical constituents of fish semen and fertility: The effect of short-term storage. Fish Physiology and Biochemistry 12 (5): 357-367.

DOI: $10.1007 / \mathrm{BF} 00004300$

Ciereszko A., Dabrowski K., Kucharczyk D., Dobosz S., Goryczko K., Glogowski J. 1999. The presence of uric acid, an antioxidantive substance, in fish seminal plasma. Fish Physiology and Biochemistry 21 (4): 313-315. DOI: $10.1023 / \mathrm{A}: 1007886121663$

Clesceri L.S., Greenberg A.E., Eaton A.D. 1998. Standard methods for the examination of water and wastewater. American Public Health Association, Washington DC, USA.

Da Rocha A.M., Salomão de Freitas D.P., Burns M., Vieira J.P., de la Torre F.R., Monserrat J.M. 2009. Seasonal and organ variations in antioxidant capacity, detoxifying competence and oxidative damage in freshwater and estuarine fishes from southern Brazil.
Comparative Biochemistry and Physiology, Part C: Toxicology and Pharmacology 150 (4): 512-520. DOI: $10.1016 /$ j.cbpc.2009.07.012

Dai W., Wang X., Guo Y., Wang Q., Ma J. 2011. Growth performance, hematological and biochemical responses of African catfish (Clarias gariepinus) reared at different stocking densities. African Journal of Agricultural Research 6 (28): 6177-6182.

DOI: $10.5897 / A J A R 11.1278$

Demska-Zakęś K., Zakęś Z., Ziomek E., Jarmołowicz S. 2012. Impact of feeding juvenile tench (Tinca tinca (L.)) feeds supplemented with vegetable oils on hematological indexes and liver histology. Archives of Polish Fisheries 20 (2): 67-75.

DOI: $10.2478 / \mathrm{v} 10086-012-0009-\mathrm{z}$

Di MarcoP.,PrioriA., Finoia M.G.,PetochiT.,LongobardiA., Donadelli V., Marino G. 2011. Assessment of blood chemistry reference values for cultured sturgeon hybrids (Acipenser naccarii female $\times$ Acipenser baerii male). Journal of Applied Ichthyology 27 (2): 584-590.

DOI: $10.1111 /$ j.1439-0426.2011.01713.x

Doumas B.T., Watson W.A., Biggs H.C. 1971. Albumin standards and management of serum albumin with bromcresol green. Clinica Chimica Acta 31 (1): 87-96. DOI: 10.1016/S0009-8981(96)06447-9

Drozd R., Panicz R., Jankowiak D., Hofsoe P., Drozd A., Sadowski J. 2014. Antoxidant enzymes in the liver and gills of Tinca tinca from various water bodies. Journal of Applied Ichthyology 30 (Suppl. 1): 2-6. DOI: $10.1111 /$ jai.12420

Enes P., Pérez-Jiménez A., Peres H., Couto A., PousãoFerreira P., Oliva-Teles A. 2012. Oxidative status and gut morphology of white sea bream, Diplodus sargus fed soluble non-starch polysaccharide supplemented diets. Aquaculture 358-359: 79-84.

DOI: $10.1016 /$ j.aquaculture.2012.06.020

Furné M., García-Gallego M., Hidalgo M.C., Morales A.E., Domezain A., Domezain J., Sanz A. 2009. Oxidative stress parameters during starvation and refeeding periods in Adriatic sturgeon (Acipenser naccarii) and rainbow trout (Oncorhynchus mykiss). Aquaculture Nutrition 15 (6): 587-595.

DOI: $10.1111 /$ j.1365-2095.2008.00626.x

González-Rodríguez Á., Celada J.D., Carral J.M., SáezRoyuela M., Fuertes J.B. 2014. Effects of varying protein level in practical diets on survival, growth, feed utilization and body composition of juvenile tench (Tinca tinca L.). Aquaculture International 22 (5): 1723-1735. DOI: 10.1007/s10499-014-9777-3

Habig W.H., Pabst M.J., Jakoby W.B. 1974. Glutathione S-transferases; The first enzymatic step in mercapturic acid formation. やJournal of Biological Chemistry 249 (22): 7130-7139.

Häder D.-P., Kumar H.D., Smith R.C., Worrest R.C. 2003. Aquatic ecosystems: Effects of solar ultraviolet radiation and interactions with other climatic change factors. Photochemical and Photobiological Sciences 2 (1): 39-50.

DOI: $10.1039 / \mathrm{B} 211160 \mathrm{H}$ 
He J., Qiang J., Gabriel N.N., Xu P., Yang R. 2015. Effect of feeding-intensity stress on biochemical and hematological indices of gift tilapia (Oreochromis niloticus). Turkish Journal of Fisheries and Aquatic Sciences 15 (2): 303-310. DOI: $10.4194 / 1303-2712-v 15212$

Hoogenboom M.O., Metcalfe N.B., Groothuis T.G.G., de Vries B., Costantini D. 2012. Relationship between oxidative stress and circulating testosterone and cortisol in pre-spawning female brown trout. Comparative Biochemistry and Physiology Part A: Molecular and Integrative Physiology 163 (3-4): 379-387. DOI: $10.1016 /$ j.cbpa.2012.07.002

Jiang W.-D., Hu K., Zhang J.-X., Liu Y., Jiang J., Wu P., Zhao J., Kuang S.-Y., Tang L., Tang W.-N., Zhang Y.-A., Zhou X.-Q., Feng L. 2015. Soyabean glycinin depresses intestinal growth and function in juvenile Jian carp (Cyprinus carpio var jian): protective effects of glutamine. British Journal of Nutrition 114 (10): 1569-1583. DOI: $10.3109 / 00365529209095998$

Katalinic V., Modun D., Music I., Boban M. 2005. Gender differences in antioxidant capacity of rat tissues determined by 2,2'-azinobis (3-ethylbenzothiazoline 6-sulfonate; ABTS) and ferric reducing antioxidant power (FRAP) assays. Comparative Biochemistry and Physiology Part C: Toxicology and Pharmacology 140 (1): 47-52.

DOI: 10.1016/j.cca.2005.01.005

Koelz H.R. 1992. Gastric acid in vertebrates. Scandinavian Journal of Gastroenterology 27 (Suppl. 193): 2-6. DOI: $10.3109 / 00365529209095998$

Kopecka J., Pempkowiak J. 2008. Temporal and spatial variations of selected biomarker activities in flounder (Platichthys flesus) collected in the Baltic proper. Ecotoxicology and Environmental Safety 70 (3): 379-391. DOI: 10.1016/j.ecoenv.2007.05.017

Kovyrshina T.B., Rudneva I.I. 2012. Comparative study of serum albumin levels in round goby Neogobius melanostomus from Black Sea and Azov Sea. International Journal of Advanced Biological Research 1 (1): 203-208.

Li Y., Schellhorn H. 2007. Rapid kinetic microassay for catalase activity. Journal of Biomolecular Techniques 18 (4): 185-187.

Lupiánez J.A., Sánchez-Lozano M.J., García-Rejón L., De la Higuera M. 1989. Long-term effect of a high-protein/non-carbohydrate diet on the primary liver and kidney metabolism in rainbow trout (Salmo gairdneri). Aquaculture 79 (1-4): 91-101. DOI: $10.1016 / 0044-8486(89) 90449-3$

Lushchak V.I. 2011. Adaptive response to oxidative stress: Bacteria, fungi, plants and animals. Comparative Biochemistry and Physiology Part C: Toxicology and Pharmacology 153 (2): 175-190.

DOI: $10.1016 /$ j.cbpc.2010.10.004

Macrì F., Rapisarda G., Marino G., De Majo M., Aiudi G. 2011. Use of laparoscopy for the evaluation of the reproductive status of tench (Tinca tinca). Reproduction in Domestic Animals 46 (1): 130-133. DOI: $10.1111 / \mathrm{j} .1439-0531.2010 .01606 . x$
Marklund S., Marklund G. 1974. Involvement of the superoxide anion radical in the autoxidation of pyrogallol and a convenient assay for superoxide dismutase. European Journal of Biochemistry 47 (3): 469-474.

DOI: $10.1111 /$ j.1432-1033.1974.tb03714.x

Mehra S., Dubey J., Bhowmik D. 2009. Hepatotoxic responses in Heteropneustus fossilis (Bloch) after oral exposure to Microcystis under laboratory conditions. American-Eurasian Journal of Toxicological Sciences 1 (2): 50-56.

Michaelsson M. 1961. Bilirubin determination in serum and urine. Scandinavian Journal of Clinical and Laboratory Investigation 13 (56): 1-79.

Mull C.G., Lowe C.G., Young K.A. 2010. Seasonal reproduction of female round stingrays (Urobatis halleri): Steroid hormone profiles and assessing reproductive state. General and Comparative Endocrinology 166 (2): 379-387.

DOI: 10.1016/j.ygcen.2009.12.009

Nelson J.S., Grande T.C., Wilson M.V.H. 2016. Fishes of the world. 5th edn. John Wiley and Sons, Hoboken NJ, USA.

Ognik K., Czech A., Stachyra K. 2013. Effect of a natural versus a synthetic antioxidant, and sex and age on the redox profile in the blood of growing turkeys. South African Journal of Animal Sciences 43 (4): 473-481. DOI: 10.4314 /sajas.v43i4.4

Olsen Y. 2011. Resources for fish feed in future mariculture. Aquaculture Environment Interactions 1 (3): 187-200. DOI: $10.3354 /$ aei00019

Paglia D.E., Valentine W.N. 1967. Studies on the quantitative and qualitative characterization of erythrocyte glutathione peroxidase. Journal of Laboratory and Clinical Medicine 70 (1): 158-169.

Panicz R., Sadowski J., Schütze H., Bergmann S.M. 2015. Temperature influence on key players of the somatotropic axis of tench, Tinca tinca (Actinopterygii: Cypriniformes: Cyprinidae). Acta Ichthyologica et Piscatoria 45 (4): 335-342.

DOI: 10.3750/AIP2015.45.4.01

Passi S., Cataudella S., Di Marco P., De Simone F., Rastrelli L. 2002. Fatty acid composition and antioxidant levels in muscle tissue of different Mediterranean marine species of fish and shellfish. Journal of Agricultural and Food Chemistry 50 (25): 7314-7322.

DOI: 10.1021/jf020451y

Piros B., Glogowski J., Kolman R., Rzemieniecki A., Domagala J., Horvath A., Urbanyi B., Ciereszko A. 2002. Biochemical characterization of Siberian sturgeon Acipenser baeri and sterlet Acipenser ruthenus milt plasma and spermatozoa. Fish Physiology and Biochemistry 26 (3): 289-295. DOI: $10.1023 / A: 1026280218957$

Przybył A., Mazurkiewicz J., Golski J. 2008. Evaluation of selected feeds differing in dietary lipids levels in feeding juveniles of wels catfish, Silurus glanis L. Acta Ichthyologica et Piscatoria 38 (2): 91-96. DOI: 10.3750/AIP2008.38.2.02 
Rabie F., Magid A.M.A., Guma'a K.A., Karrar O. 1972. Evolution of catalase in fish. Comparative Biochemistry and Physiology Part A: Physiology 43 (4): 1053-1055. DOI: 10.1016/0300-9629(72)90177-6

Roy S., Bhattacharya S. 2006. Arsenic-induced histopathology and synthesis of stress proteins in liver and kidney of Channa punctatus. Ecotoxicology and Environmental Safety 65 (2): 218-229. DOI: 10.1016/j.ecoenv.2005.07.005

Rudneva I.I. 1997. Blood antioxidant system of Black Sea elasmobranch and teleosts. Comparative Biochemistry and Physiology Part C: Toxicology and Pharmacology 118 (2): 255-260.

DOI: $10.1016 / \mathrm{S} 0742-8413(97) 00111-4$

Sadowski J., Filipiak J., Trzebiatowski R. 1998. Effects of different duration of feeding on results of carp (Cyprinus carpio) fry cage culture in cooling water. Electronic Journal of Polish Agricultural Universities 1 (1): \#02.

Sanchez W., Aït-Aïssa S., Palluel O., Ditche J.-M., Porcher J.-M. 2007. Preliminary investigation of multi-biomarker responses in three-spined stickleback (Gasterosteus aculeatus L.) sampled in contaminated streams. Ecotoxicology 16 (2): 279-287.

DOI: $10.1007 / \mathrm{s} 10646-006-0131-\mathrm{z}$

Shahsavani D., Kazerani H.R., Kaveh S., GholipourKanani H. 2010. Determination of some normal serum parameters in starry sturgeon (Acipenser stellatus Pallas, 1771) during spring season. Comparative Clinical Pathology 19 (1): 57-61.

DOI: 10.1007/s00580-009-0899-3

Sen P.R., Rao N.G.S., Ghosh S.R., Rout M. 1978. Observations on the protein and carbohydrate requirements of carps. Aquaculture 13 (3): 245-55. DOI: 10.1016/0044-8486(78)90006-6

Sitar M.E., Aydin S., Çakatay U. 2013. Human serum albumin and its relation with oxidative stress. Clinical Laboratory 59 (9): 945-952.

DOI: 10.7754/Clin.Lab.2012.121115

Tacon A.G.J., Halwart M. 2007. Cage culture: A global overview. Pp. 3-16. In: Halwart M., Soto D., Arthur J.R. (eds.) Cage aquaculture-Regional reviews and global overview. FAO Fisheries Technical Paper No. 498. FAO, Rome.

Thefeld W., Hoffmeister H., Busch E.-W., Koller P.U., Vollmar J. 1973. Normalwerte de Serumharnsäure in Abhängigkeit von Alter und Geschlecht mit einem neuen enzymatischen Harnsäurefarbtest. Deutsche Medizinische Wochenschrift 98 (8): 380-384.

DOI: $10.1055 / \mathrm{s}-0028-1106819$

Tietz N.W. 1999. Textbook of clinical chemistry. W.B. Saunders, Philadelphia, PA, USA.

Tkachenko H., Kurhaluk N., Grudniewska J. 2013. Biomarkers of oxidative stress and antioxidant defences as indicators of different disinfectants exposure in the heart of rainbow trout (Oncorhynchus mykiss Walbaum). Aquaculture Research 46 (3): 679-689.

DOI: 10.1111/are.12214

Valko M., Leibfritz D., Moncol J., Cronin M.D., Mazur M., Telser J. 2007. Free radicals and antioxidants in normal physiological functions and human disease. International Journal of Biochemistry and Cell Biology 39 (1): 44-84.

DOI: 10.1016/j.biocel.2006.07.001

Vega-López A., Galar-Martínez M., Jiménez-Orozco F.A., García-Latorrec E., Domínguez-López M.L. 2007. Gender related differences in the oxidative stress response to $\mathrm{PCB}$ exposure in an endangered goodeid fish (Girardinchthys viviparus). Comparative Biochemistry and Physiology Part A: Molecular and Integrative Physiology 146 (4): 672-678.

DOI: $10.1016 /$ j.cbpa.2006.04.022

Vinagre C., Madeira D., Narciso L., Cabral H.N., Diniz M. 2012. Effect of temperature on oxidative stress in fish: Lipid peroxidation and catalase activity in the muscle of juvenile seabass, Dicentrarchus labrax. Ecological Indicators 23: 274-279.

DOI: 10.1016/j.ecolind.2012.04.009

Williams D.E., Masters B.S.S., Lech J.J., Buhler D.R. 1986. Sex differences in cytochrome P-450 isozyme composition and activity in kidney microsomes of mature rainbow trout. Biochemical Pharmacology 35 (12): 2017-2023.

DOI: 10.1016/0006-2952(86)90735-5

Yousefian M., Amiri M.S., Hedayatifard M., Dehpour A.A., Fazli H., Ghiaci M., Farabi S.V., Najafpour S.H. 2010. Serum biochemical parameter of male and female rainbow trout (Onchorhynchus mykiss) cultured in Haraz River, Iran. World Journal of Fish and Marine Sciences 2 (6): 513-518.

Zhang X.-d., Wu T.-x., Cai L.-s., Zhu Y.-f. 2007. Influence of fasting on muscle composition and antioxidant defenses of market-size Sparus macrocephalus. Journal of Zhejiang University SCIENCE B 8 (12): 906-911.

DOI: 10.1631/jzus.2007.B0906

Yilmaz E., Akyurt I., Mutlu E. 2006. Effects of energetic diets on growth, blood chemistry, and liver pathology of African catfish, Clarias gariepinus (Burchell 1822). The Israeli Journal of Aquaculture-Bamidgeh 58 (3): 191-197.

Received: 11 October 2016 Accepted: 16 May 2017 Published electronically: 30 September 2017 